\title{
A NUTRITIONAL STUDY OF IRISH ATHLETES
}

\author{
A. BARRY, Dip.Dietetics \& Nutrition, ${ }^{*}$ T. CANTWELL, BSc, PhD, ${ }^{*}$ F. DOHERTY, BSc, BA(Mod), MNS, \\ Jean C. FOLAN, BSc, MB, BCh, BAO, ${ }^{*}$ M. INGOLDSBY, MSc, Dip.Dietetics \& Nutrition, *** \\ J. P. KEVANY, MB, MPH, FFCM, * * J. D. O'BROIN, MSc, HDipEd, † H. O'CONNOR, Dip.Dietetics \& Nutrition, $\neq$ \\ B. O'SHEA, MSc, PhD, ${ }^{*}$ B. A. RYAN, MSc, MIBiol, MICI, AIST* and J. VAUGHAN, FIMLS* \\ Irish Sports Nutrition Centre \\ * Dublin Institute of Technology, College of Technology, Kevin Street, Dublin 8 \\ * *Trinity College, College Green, Dublin 2 \\ ***St. Catherine's College of Home Economics, Blackrock, Co. Dublin \\ $\$$ Meath Hospital, Dublin 8 \\ tTrinity Medical School, St. James's Hospital, Dublin 8
}

\begin{abstract}
The aims of this study were (1) to carry out a nutritional assessment of selected Irish athletes and (2) to provide individual results and specific advice to each athlete on how to achieve an optimum diet.

Dietary intakes were measured by a three-day weighed dietary record technique designed to evaluate each athlete's usual eating habits. The results were evaluated against a set of dietary standards in order to determine adequacy.

Nutritional status was also assessed in a limited form by selected anthropometric and biochemical measurements.

A total of 148 subjects took part in the assessment which began in May, 1979 and continued until April, 1980. The sports involved included: canoeing, cycling, rowing, swimming, hockey, squash and track and field events.

The results indicated a range of sub-optimal dietary patterns relating in particular to abnormal intakes of folate, iron, pyridoxine and calcium. The significance and applications of these findings are discussed.
\end{abstract}

\section{INTRODUCTION}

The identification and selection of top national athletes by the Irish Olympic Committee prior to the 1980 Olympic Games provided a convenient opportunity to study under controlled conditions the dietary and nutritional status of subjects showing their best performance standards in a range of officially recognised activities. The study was extended to include club-class athletes competing in the same activity categories to provide a group of lower performance standards for comparative purposes. The specific objectives of the study were:

(a) To assess existing dietary intake and nutritional status.

(b) To correct major abnormalities of intake as a contribution to improved fitness, and

(c) To generate material for educational and research purposes.

The study was undertaken during the period May,
1979-April, 1980 by the Dublin Institute of Technology in collaboration with Dublin University and involved a team of dietitians, physicians, biochemists and a computer scientist. Financial support for this undertaking was provided in part by the National Dairy Council of Ireland.

\section{SAMPLING}

The sample frame consisted of all potential competitors for the 1980 Olympic Games in Moscow, who were nominated by their respective organisations through the Irish Olympic Council (IOC). The study sample consisted of those who were willing to participate in the assessment programme, which represented approximately a $90 \%$ response. In addition, a non-random volunteer sample of club athletes following a regular training schedule, participated in the programme.

The total sample was divided into two classes: international/Olympic class (I-Class) and club class (C-Class). This provided a total sample of 143 subjects of which 108 were international class (87 males: 21 females) 
and 35 were club class (28 males: 7 females). These classes were further divided according to the activity level of the various events, in accordance with a modified version of the biomechanical classification of sports suggested by Dal Monte (1969) and presented in Table I.

The predominance of men in the sample $(80 \%)$ reflects the usual sex distribution in international competition and in similar studies of this kind, FerroLuzzi, Topi et al (1975) and Steele (1970).

It can be noted from Table I that the majority of male participants were concentrated in activity categories 1, 2 and 3, the principal events being cycling, marathon and middle-distance running, hockey, squash, boxing, swimming, rowing and canoeing. For females, activity category 3 was the most concentrated, the principal events being middle-distance running and swimming.

\section{TABLE I}

Definition of activity categories and distribution of athletes

\begin{tabular}{|c|c|c|c|c|}
\hline \multirow[b]{2}{*}{ Code } & \multirow{2}{*}{$\begin{array}{l}\text { Activity } \\
\text { Categories }\end{array}$} & \multicolumn{2}{|c|}{ Subjects } & \multirow[b]{2}{*}{ Type of Sport } \\
\hline & & Male & Female & \\
\hline 1 & Aerobic effort & 32 & 6 & $\begin{array}{l}\text { Cycling, Marathon } \\
\text { Track \& Field - } \\
1500,5000,10,000 \mathrm{~m} \\
\text { Orienteering }\end{array}$ \\
\hline 2 & $\begin{array}{l}\text { Alternate aerobic } \\
\text { and anaerobic } \\
\text { effort }\end{array}$ & 32 & 7 & $\begin{array}{l}\text { Hockey, Squash } \\
\text { Boxing, Basketball } \\
\text { Judo }\end{array}$ \\
\hline 3 & $\begin{array}{l}\text { Massive aerobic } \\
\text { and anaerobic } \\
\text { effort }\end{array}$ & 32 & 10 & $\begin{array}{l}\text { Swimming, Rowing, } \\
\text { Canoeing, Track \& } \\
\text { Field }(400 \mathrm{mH} \text {, } \\
400 \mathrm{~m}, 800 \mathrm{~m})\end{array}$ \\
\hline 4 & Power activity & 2 & 3 & $\begin{array}{l}\text { Track \& Field } \\
(100 \mathrm{~m}, 200 \mathrm{~m}) \\
\text { High Jump, Shot, } \\
\text { Hammer, Decathlon }\end{array}$ \\
\hline 5 & $\begin{array}{l}\text { Skill activity } \\
\text { (relevant muscular } \\
\text { effort) }\end{array}$ & 10 & 1 & $\begin{array}{l}\text { Equestrian } \\
\text { Yachting }\end{array}$ \\
\hline 6 & $\begin{array}{l}\text { Skill activity } \\
\text { (little muscular effe }\end{array}$ & 7 & 1 & Archery, Shooting \\
\hline
\end{tabular}

It is also evident from Table I that a sizeable proportion of men are in categories 5 and 6 - activities requiring little or no muscular effort (e.g. equestrian, archery, shooting). The potential bias in anthropometric, dietary and biochemical results introduced by this sendentary group will be referred to later in the text.

\section{METHODS}

The areas of assessment of nutritional status were broken down as follows:

Nutrition : dietary
Haematology
Biochemistry
urther details are given below:

\section{Dietary Methodology}

The method used, a modified version of the weighed inventory method described by Marr (1971), was aimed at obtaining a weighed record of all food consumed (including drink) over a period of three days. Alternate days were chosen as this is deemed more representative of usual consumption patterns than consecutive days. It was stipulated however, that none of these days be a competition day, if this involved a substantial change in intake.

The recording procedure was divided into three stages:

(1) Foods consumed frequently, e.g. butter, sugar and preserves, were weighed in bulk prior to the survey period. A further weighing at the end of the survey period gave the amount consumed. Milk, because of its perishable nature, was set aside prior to each survey day and a further weighing at the end of the survey day gave the amount consumed.

(2) All edible food eaten in the home was weighed prior to consumption; plate waste, of which there was very little, was also recorded.

(3) All food eaten outside the home was recorded with the aid of comprehensive guidelines.

The dietary records were analysed for the following parameters: energy, protein, fat, carbohydrate, percentage energy derived from protein, fat and carbohydrate; minerals:- iron, calcium, magnesium, vitamins:thiamin, riboflavin, nicotinic acid, ascorbic acid (vitamin C), pyridoxine (B6), folate, cyanocobalamin (B12); dietary fibre and cholesterol.

Results were expressed as a mean of the 3-day recorded intake. Food Composition data were taken from "The Composition of Foods", by McCance and Widdowson, edited by Paul and Southgate (1978), which was incorporated in a computer data base.

\section{Anthropometry}

The following anthropometric data were recorded for all participants:

Height $(\mathrm{cm})$ in stockinged feet

Weight $(\mathrm{kg})$ in minimum daily clothing

Triceps skinfold $(\mathrm{mm})$

Upper arm circumference $(\mathrm{cm})$ 


\section{Haematology}

A routine haematological assessment was carried out for each participant. This included haemoglobin, haematocrit, mean corpuscular haemoglobin concentration, erythrocyte sedimentation rate, red and white cell counts, and blood film examination.

\section{Biochemistry}

Biochemical assessment using standard methods, included blood glucose, total cholesterol and HDL. cholesterol, triglyceride, total protein, serum iron and total iron binding capacity, serum vitamin B12, serum and red cell folates and serum ferritin. Details of the methods used are available on request.

\section{ASSESSMENT PROCEDURE}

The assessment methods just described were carried out in The Dublin Institute of Technology, College of Technology, Kevin Street, (hereinafter referred to as "the Centre"). Participants attended the Centre in groups of approximately twenty. A standard study protocol which explained the aims of the Centre and the procedures involved was provided. A verbal explanation of the procedures was also given, with the opportunity for any questions. Details of dietary supplements were recorded. (Each participant was given a data sheet listing the tests to be carried out which he retained during the assessment and handed up at the end of the morning. This document served both as a check list and to record anthropometric measurements.) Anthropometric measurements and a blood sample were taken and dietary recording instructions were given. Each participant received a personal demonstration, with actual food samples, in the use of a dietary scales, and was provided with an identical scales (with taring capacity for recording to the nearest $5 \mathrm{~g}$ or $1 / 4 \mathrm{Oz}$ ), recording sheets and instructions.

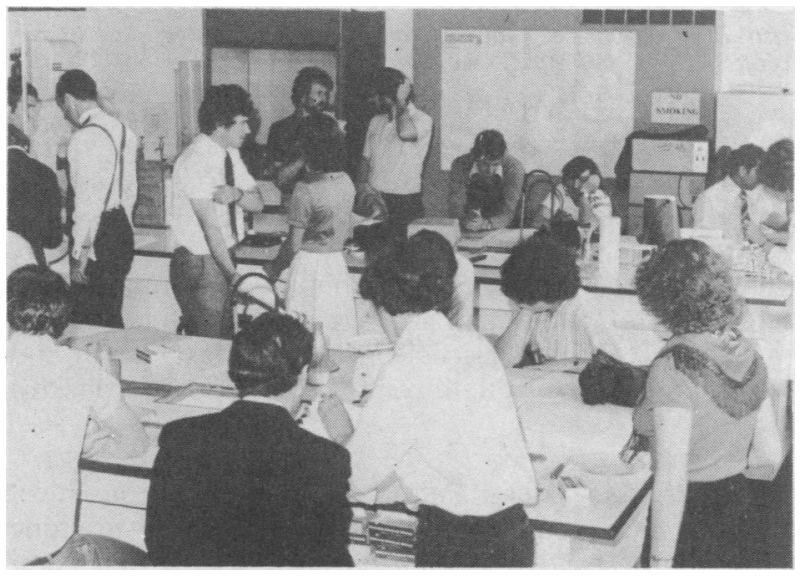

Fig. 1

Overivew of group session at Sports Nutrition Centre, College of Technology, Kevin Street, Dublin
In addition to the dietary recordings to be carried out at home, each participant kept an account of their training schedule during the recording period. Details of time, duration and intensity of the physical activity performed were recorded. This information was used later as a basis for advice relating to meal patterns (see Dietary Advice section). During the course of the study, participants had access to the nutrition staff of the Centre to resolve any problems that arose.

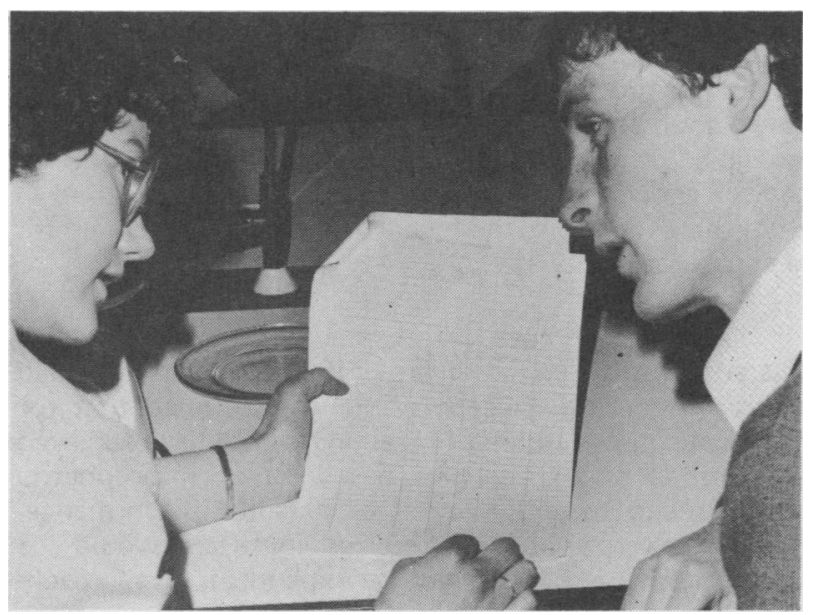

Fig. 2 Dietary recording advice to athlete

\section{DIETARY STANDARDS}

The following table (Table II) presents values for the selected dietary reference standards used in this study.

TABLE II

\section{Dietary reference standards}

Nutrient

Protein Cholesterol

Fibre

Thiamin (mg/1000 kcal)

Riboflavin ( $\mathrm{mg} / 1000 \mathrm{kcal}$ )

Nicotinic Acid (mg/1000 kcal)

Ascorbic Acid

Pyridoxine

Folate

Iron

Calcium Magnesium

\section{Amount

Men Women

(g) $\quad$ lg/kg body wt/day

20

Ig/kg body wt/day

(g)

20

0.55

0.55

6.6

60

2.0

300

3

2.0

300

3

18

800 (mg) $\quad 300$ 
Dietary intake standards were established on the basis of recommendations for appropriate age/sex categories of general populations as, for most nutrients, no specific standards exist for athletes. As Ireland has not developed independent standards for its own population, population recommendations prepared by the Department of Health and Social Security of the U.K. (1969), the Food and Nutrition Board of the National Academy of Sciences of the U.S.A. (1974) and the World Health Organisation (1974) were used as scientifically based sources. In view of the active nature of most athletic events and the demands of training, it was decided to select the highest recommended intake value from the three sources given above, for the appropriate age/sex category. Thus, with the exception of protein, cholesterol and fibre, the array of dietary standards used in this study represent the highest values recommended for general populations.

Standards for energy intake were not specified for this study as the range of requirements obviously varied greatly according to activity. It was assumed that for most categories, athletes in training would have achieved an optimal energy balance based on normal appetite controls and the observation of personal performance. Possible exceptions to these assumptions would be Categories 5 and 6 where energy expenditure is relatively low and intermittent, and where performance is dependent more on eye-limb co-ordination than on biomechanical power. Under these conditions, physical activity is only a minor determinant of energy requirement.

The standard for protein $(\mathrm{lg} / \mathrm{kg}$ body $\mathrm{wt} /$ day) is based on the conclusions of Durnin et al (1978), this being one of the few attempts to interpret the conflicting results of the many investigations devoted to protein requirements of athletes. A tentative standard for cholesterol was derived from current international recommendations on intake for the prevention of heart disease by the Senate Select Committee on Nutrition and Human Needs (1977), whilst the fibre standard represented the upper range of normal values encountered in Irish dietary surveys O'Shea (1979).

\section{DATA PROCESSING}

Data were transferred from the standard collection forms to cards and stored on computer files for subsequent analysis. Means and standard deviations were calculated for the 19 dietary parameters, 4 anthropometric parameters and 15 haematological and biochemical parameters as listed in the methodology, for sub-groups defined by age, sex and activity category.

The Pearson correlation coefficient was evaluated for a selection of paired parameters and significance levels calculated from evaluating the ratio of $r$ to the standard error of $r$ and equating this to $t$ with $n-2$ degrees of freedom. The selection of the paired parameters was indicated by the recognised or anticipated relationship between certain dietary, biochemical, haematological or anthropometric measurements.

\section{DIETARY ADVICE}

When the results became available, each athlete was given a full comparison of his recorded intake against the dietary reference standards. This showed at a glance any major abnormalities of intake. In addition, more comprehensive written dietary advice was given, taking into account the 3-day food record, and presented under the following headings:

(1) Adequacy of Dietary Intake: This section informed the athlete whether his diet was adequate or not in the nutrients analysed. It then listed the nutrients, if any, which did not meet the required standards.

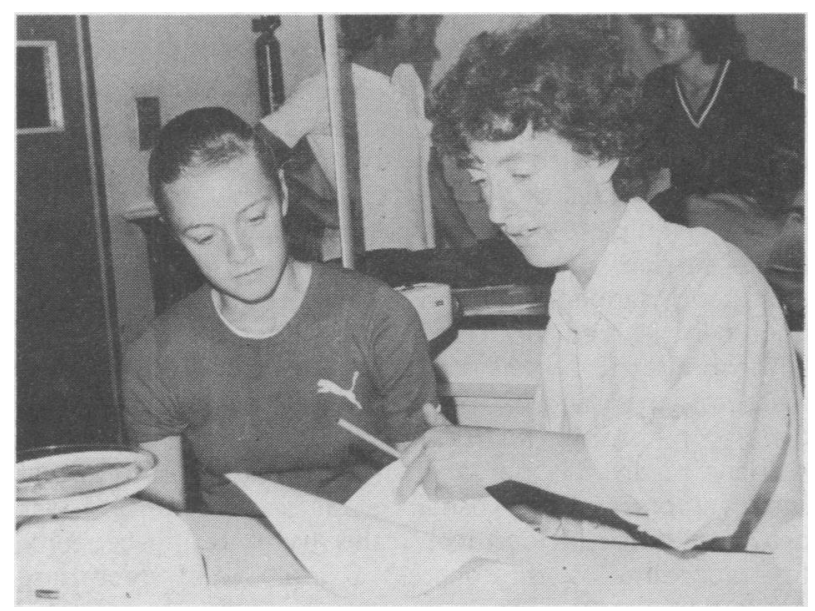

Fig. 3

Irish international Athlete Carol Meagan with Ms. Ann Barny (dietician), explaining the weighed dietary method

(2) Foods to Increase or Decrease: Specific foods were identified as a means of increasing (or decreasing) nutrient intakes found to be deficient (or in excess).

(3) Dietary Fibre Content: When this was found to be below the reference standard, a selection of foods with a high fibre content was listed for breakfast, lunch and evening meal. The athlete was asked to choose from this list.

(4) Desirable Meal Patterns: Comments on meal pattern were made with reference to the training schedule for each recording day. Frequency and composition of meals were considered in relation to time, duration and intensity of training. Advice on how to improve meal patterns was given where necessary. 
(5) Use of Snack Foods: A list of nutritious snack foods was given when the athlete's choice of such foods was found to be unsuitable and especially when this occurred in conjunction with major nutrient abnormalities.

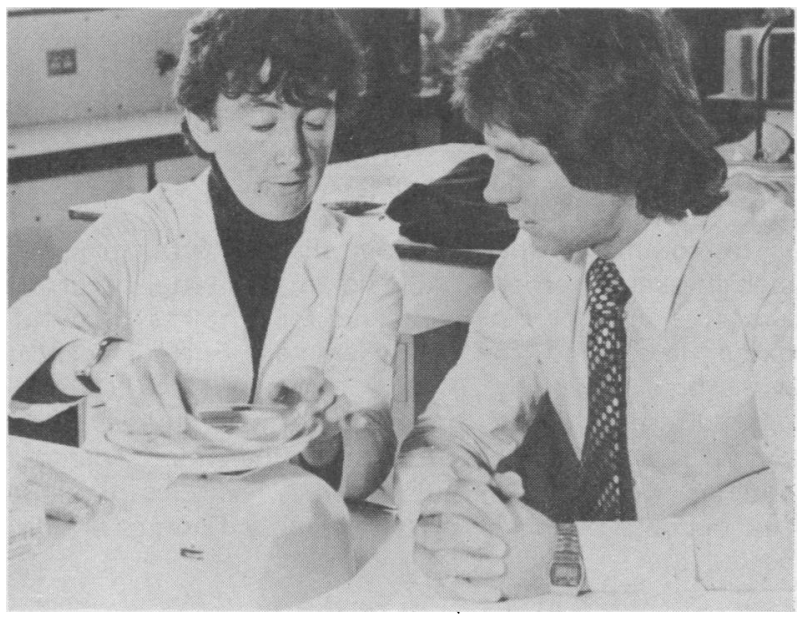

Fig. 4

World indoor mile record holder Eamonn Coghlan with Ms. Ann Barry

(6) Menu Planning: This section gave practical advice for planning meals based on sections 1 and 2. Recommendations on the 3 main meals of the day were subdivided into 3 sections: these gave the athlete guidance on the foods to "include", "substitute" and "eliminate" at each main meal, as a means of correcting any dietary abnormalities found.

This advice was well accepted by the athletes and resulted in further requests from many of their colleagues to avail of the Centre's facilities.

\section{DIETARY RESULTS}

The results of the dietary assessment are presented in Tables III and IV. Mean total energy intakes showed a wide variation ranging from 2609 to $4002 \mathrm{kcal}$ per day. However, values for energy intake on a body weight basis showed remarkable consistency.

When total energy intake values were broken down by activity category and looked at in descending order of magnitude the following became evident: Category 3, involving massive aerobic-anaerobic effort such as swimming and rowing had the highest intake of 4793 kcals per day; category 4, power activity, came next with a mean intake of $4361 \mathrm{kcals} /$ day followed by category 1, aerobic effort, with $4062 \mathrm{kcals} / \mathrm{day}$. The women followed a similar order (categories $3,4,5$ ) but
TABLE III

Macronutrient intakes

\begin{tabular}{|c|c|c|c|c|c|}
\hline & & MEN & & wo & MEN \\
\hline & $\begin{array}{l}\text { Reference } \\
\text { Standard }\end{array}$ & $\frac{\text { t-Clas }}{\bar{X}} \pm$ SD & $\frac{C-C l e s s}{\bar{X}} \pm S D$ & $\frac{1-\text { Class }}{\bar{X} \pm S D}$ & $\frac{\mathrm{C}-\mathrm{Clans}}{\overline{\mathrm{X}} \pm \mathrm{SD}}$ \\
\hline Total Energy (MJ) & - & $\begin{array}{r}16.8 \\
\pm \quad 4.3\end{array}$ & $\begin{array}{r}16.3 \\
\pm \quad 3.8\end{array}$ & $\begin{array}{r}11.8 \\
\pm \quad 3.6\end{array}$ & $\begin{array}{r}10.9 \\
+\quad 2.9\end{array}$ \\
\hline $\begin{array}{l}\text { Total Energy } \\
\text { (kcals) }\end{array}$ & - & $\begin{array}{r}4002 \\
\pm 1039\end{array}$ & $\begin{array}{l}3889 \\
\pm 904\end{array}$ & $\begin{array}{l}2818 \\
\pm 858\end{array}$ & $\begin{array}{l}2609 \\
\pm 696\end{array}$ \\
\hline $\begin{array}{l}\text { Energy } \\
\text { (kJ/kg b.w./day) }\end{array}$ & - & $\begin{array}{r}209.7 \\
\pm \quad 51.1\end{array}$ & $\begin{array}{r}213.9 \\
\pm \quad 47.3\end{array}$ & $\begin{array}{r}208.5 \\
\pm 55.7\end{array}$ & $\begin{array}{r}221.4 \\
\pm \quad 72.0\end{array}$ \\
\hline $\begin{array}{l}\text { Energy } \\
\text { (kcals/kg b.w./day) }\end{array}$ & ) & $\begin{array}{r}50.1 \\
\pm \quad 12.2\end{array}$ & $\begin{array}{r}51.0 \\
+\quad 11.3\end{array}$ & $\begin{array}{r}49.8 \\
+\quad 13.3\end{array}$ & $\begin{array}{r}52.9 \\
\pm 17.2\end{array}$ \\
\hline Total Protein (g) & - & $\begin{array}{r}152 \\
\pm \quad 48\end{array}$ & $\begin{array}{r}136 \\
\pm \quad 31\end{array}$ & $\begin{array}{r}108 \\
\pm \quad 34\end{array}$ & $\begin{array}{r}88 \\
\pm 29\end{array}$ \\
\hline $\begin{array}{l}\text { Protein } \\
\text { (g/kg b.w./day) }\end{array}$ & 1.0 & $\begin{array}{r}2.0 \\
\pm \quad 0.5\end{array}$ & $\begin{array}{r}1.9 \\
+\quad 0.5\end{array}$ & $\begin{array}{r}1.8 \\
\pm \quad 0.6\end{array}$ & $\begin{array}{r}1.8 \\
\pm \quad 0.5\end{array}$ \\
\hline Fat $(g)$ & & $\begin{array}{r}178 \\
\pm 56\end{array}$ & $\begin{array}{r}164 \\
\pm \quad 38\end{array}$ & $\begin{array}{r}133 \\
\pm 60\end{array}$ & $\begin{array}{r}122 \\
\pm \quad 33\end{array}$ \\
\hline Cholesterol (mg) & 300 & $\begin{array}{r}634 \\
\pm 412\end{array}$ & $\begin{array}{r}487 \\
\pm 192\end{array}$ & $\begin{array}{r}514 \\
\pm 209\end{array}$ & $\overline{-}$ \\
\hline Carbohydrate (g) & & $\begin{array}{r}454 \\
\pm 134\end{array}$ & $\begin{array}{r}461 \\
\pm 132\end{array}$ & $\begin{array}{r}338 \\
\pm 100\end{array}$ & $\begin{array}{r}304 \\
\pm \quad 86\end{array}$ \\
\hline Fibre (g) & 20 & $\begin{array}{r}29 \\
\pm \quad 14\end{array}$ & $\begin{array}{r}30 \\
\pm \quad 11\end{array}$ & $\begin{array}{r}22 \\
\pm \quad 5\end{array}$ & $\begin{array}{r}21 \\
\pm \quad 7\end{array}$ \\
\hline
\end{tabular}

PERCENTAGE OF ENERGY DERIVED FROM

$\begin{array}{lccrrrrr}\text { Protein } & 10-15 \% & 15.5 & 14.6 & 14.9 & 13.4 \\ & & \pm 2.4 \pm 2.1 & \pm 2.0 \pm 1.7 \\ \text { Fat } & 35 \% & 40.7 & 39.3 & 40.1 & 42.4 \\ & & \pm 5.8 \pm & 5.1 & \pm & 8.4 \pm & 3.3 \\ \text { Carbohydrate } & 50-55 \% & 43.8 & 45.8 & 45.0 & 44.2 \\ & & \pm 6.3 \pm & 6.0 & \pm & 8.3 \pm & 3.4\end{array}$

I = International Olympic athlete

$\mathrm{C}=$ Club athlete

on a lower scale of energy intake, 3212, 3048 and 2808 $\mathrm{kcals} /$ day respectively.

Protein intakes were high, almost double the reference value of $\mathrm{lg} / \mathrm{kg} / \mathrm{body} \mathrm{wt} /$ day. Total protein intakes vary with class and sex, whereas when protein intakes are related on a body weight basis there is very close proximity in the results (men, (I) 2.0 and (C) 1.9 , women, $(I+C) 1.8 \mathrm{~g} / \mathrm{kg}$ body weight/day).

When the contribution of the three major nutrients are looked at in relation to total energy intake, a moderately high protein (13.4-15.5\%), a high fat (39.3-42.4\%) and a relatively low carbohydrate intake (43.8-45.8\%) can be observed.

The mean fibre intakes were high but there was large individual variation which can be noted from the high standard deviations. 
Values for the mean intakes and standard deviations of the dietary vitamins and minerals analysed are shown in Table IV. The first three of these, thiamin, riboflavin and nicotinic acid are expressed in units of $\mathrm{mg} / 1000$ kcals, their intake being closely related to the body's energy metabolism.

\section{TABLE IV}

\section{Micronutrient intakes}

\begin{tabular}{|c|c|c|c|c|c|}
\hline & \multicolumn{3}{|c|}{ MEN } & \multicolumn{2}{|c|}{ WOMEN } \\
\hline & $\begin{array}{l}\text { Reference } \\
\text { Standard }\end{array}$ & $\begin{array}{l}\text { I-Class } \\
\overline{\mathbf{X}} \pm \text { SD }\end{array}$ & $\begin{array}{l}\text { C-Class } \\
\bar{X} \pm S D\end{array}$ & $\begin{array}{l}\text { I-Class } \\
\bar{X} \pm S D\end{array}$ & $\begin{array}{l}\text { C-Class } \\
\overline{\mathbf{X}} \pm \text { SD }\end{array}$ \\
\hline $\begin{array}{l}\text { Thiamin } \\
\text { (mg/1000 kcals) }\end{array}$ & 0.4 & $\begin{array}{r}0.59 \\
\pm 0.16\end{array}$ & $\begin{array}{r}0.63 \\
\pm 0.27\end{array}$ & $\begin{array}{r}0.59 \\
\pm 0.16\end{array}$ & $\begin{array}{r}0.58 \\
\pm 0.15\end{array}$ \\
\hline $\begin{array}{l}\text { Riboflavin } \\
\text { (mg/1000 kcals) }\end{array}$ & 0.55 & $\begin{array}{r}1.00 \\
\pm 0.30\end{array}$ & $\begin{array}{r}0.92 \\
0 \pm 0.28\end{array}$ & $\begin{array}{r}0.97 \\
\pm 0.29\end{array}$ & $\begin{array}{r}0.99 \\
\pm 0.15\end{array}$ \\
\hline $\begin{array}{l}\text { Nicotinic Acid } \\
\text { (mg/1000 kcals) }\end{array}$ & 6.6 & $\begin{array}{r}9.3 \\
\pm 4.6\end{array}$ & $\begin{array}{r}12.7 \\
\pm \quad 4.3\end{array}$ & $\begin{array}{r}8.7 \\
\pm 4.1\end{array}$ & $\begin{array}{r}16.6 \\
\pm \quad 2.2\end{array}$ \\
\hline Pyridoxine (mg) & 2 & $\begin{array}{r}2.2 \\
\pm 0.8\end{array}$ & $\begin{array}{r}2.0 \\
\pm 0.4\end{array}$ & $\begin{array}{r}1.5 \\
\pm 0.5\end{array}$ & $\begin{array}{r}1.3 \\
\pm 0.4\end{array}$ \\
\hline $\begin{array}{l}\text { Ascorbic Acid } \\
\text { (mg) }\end{array}$ & 60 & $\begin{array}{l}103.1 \\
\pm 61.3\end{array}$ & $\begin{array}{r}82.3 \\
\pm 25.1\end{array}$ & $\begin{array}{r}87.7 \\
\pm 43.0\end{array}$ & $\begin{array}{r}50.8 \\
\pm 28.6\end{array}$ \\
\hline Folate $(\mu \mathrm{g})$ & 300 & $\begin{array}{l}312.4 \\
\pm 23.2\end{array}$ & $\begin{array}{l}317.4 \\
\pm 93.2\end{array}$ & $\begin{array}{l}200.4 \\
\pm 67.4\end{array}$ & $\begin{array}{l}178.0 \\
\pm 73.1\end{array}$ \\
\hline Cyanocobalamin & 3 & 19.2 & 13.2 & 3.0 & 5.9 \\
\hline$(\mu g)$ & & \pm 28.7 & \pm 17.2 & \pm 2.2 & \pm 5.4 \\
\hline Calcium (mg) & 800 & $\begin{array}{l}1984 \\
\pm 359.6\end{array}$ & $\begin{array}{l}1824 \\
\pm 738.1\end{array}$ & $\begin{array}{l}1416 \\
\pm 674.8\end{array}$ & $\begin{array}{l}1190 \\
\pm 263.2\end{array}$ \\
\hline Iron (mg) & $\begin{array}{l}\text { M10 } \\
\text { F18 }\end{array}$ & $\begin{array}{c}21 \\
\pm \quad 7.2\end{array}$ & $\begin{array}{c}20 \\
\pm \quad 5.6\end{array}$ & $\begin{array}{c}14 \\
\pm \quad 3.3\end{array}$ & $\begin{array}{c}13 \\
\pm \quad 3.8\end{array}$ \\
\hline Magnesium (mg) & $\begin{array}{l}\text { M350 } \\
\text { F300 }\end{array}$ & $\begin{array}{c}546 \\
\pm 232.8\end{array}$ & $\begin{array}{c}515 \\
\pm 133.8\end{array}$ & $\begin{array}{l}349 \\
\pm 98.3\end{array}$ & $\begin{array}{l}356 \\
\pm 80.6\end{array}$ \\
\hline
\end{tabular}

It can be noted that thiamin intakes were satisfactory, while riboflavin values were almost double the standard $(0.55 \mathrm{mg} / 1000 \mathrm{kcals})$, due mainly to the large milk consumption. Values for nicotinic acid intake, as with riboflavin were high, again almost double the reference standard. Pyridoxine intakes were low in females, with values of 1.5 and $1.3 \mathrm{mg}$ compared with the reference standard of $2 \mathrm{mg}$.

High ascorbic acid intakes were found generally except in some categories of female athletes whose diets contained less citrus fruits and juices. Similarly, female club athletes had noticeably lower intakes of folate $(178.0 \mu \mathrm{g})$ than their international class counterparts $(200.4 \mu \mathrm{g})$, neither group reaching the required standard of $300 \mu \mathrm{g}$.

Cyanocobalamin (B12) intakes showed great variation with particularly high values in males compared with females, due mainly to their relatively higher consumption of animal products.
It is evident that calcium intakes were high in all groups, especially in the men, whose mean intakes (1984 $\mathrm{mg}$ and $1824 \mathrm{mg}$ ) were noted to be more than double the reference standard of $800 \mathrm{mg}$. This point is enlarged on in the discussion. The women showed no indication of excessive calcium intakes.

Intake values for iron were twice the quoted reference standard for men, whereas the women's dietary iron intakes fell well below the standard of 18 $\mathrm{mg}$. Magnesium intakes were found to be high in the men and adequate in the women.

In summary, the principal dietary findings were: high intakes of protein and calcium, the latter occurring almost exclusively in men, and low intakes of pyridoxine, folate and iron in the women. Further analysis with breakdown by activity category revealed suboptimal ascorbic acid intakes for female athletes (categories 1 and 2). Fibre intakes of the more sedentary athletes were also unsatisfactory. The dietary cause and possible biological effect of these findings are discussed later.

\section{DIETARY SUPPLEMENTS}

Comprehensive details of dietary supplements currently taken by the athletes were also recorded. It was found that approximately half the participants $(54.5 \%)$, were supplementing their diets, but only $45 \%$ of this supplemented group were taking medically prescribed preparations.

The range of supplements taken by the athletes was wide, including iron (with or without folate), ascorbic acid and various multivitamin preparations.

\section{ANTHROPOMETRIC RESULTS}

The results of the anthropometric assessment are presented below in Table $\mathrm{V}$.

\section{TABLE V}

\section{Anthropometric results}

\begin{tabular}{|c|c|c|c|c|}
\hline & \multicolumn{2}{|c|}{ MEN } & \multicolumn{2}{|c|}{ WOMEN } \\
\hline & $\frac{\mid-C l a s s}{\bar{X} \pm S D}$ & $\begin{array}{l}\text { C-Class } \\
\bar{X} \pm \text { SD }\end{array}$ & $\frac{1-C l a s s}{\bar{X} \pm S D}$ & $\begin{array}{l}\text { C-Class } \\
\bar{X} \pm S D\end{array}$ \\
\hline Height $(\mathrm{cm})$ & $\begin{array}{r}178.1 \\
\pm 8.3\end{array}$ & $\begin{array}{l}173.5 \\
\pm 6.35\end{array}$ & $\begin{array}{r}165.2 \\
\pm 4.4\end{array}$ & $\begin{array}{r}160.5 \\
\pm 5.7\end{array}$ \\
\hline Weight (kg) & $\begin{array}{r}74.3 \\
\pm 10.8\end{array}$ & $\begin{array}{r}73.0 \\
\pm \quad 7.38\end{array}$ & $\begin{array}{r}59.1 \\
\pm 8.8\end{array}$ & $\begin{array}{r}55.3 \\
\pm \quad 3.9\end{array}$ \\
\hline $\begin{array}{l}\text { Body Mass Index } \\
\mathrm{wt}(\mathrm{g}) / \mathrm{ht}(\mathrm{cm})^{2}\end{array}$ & $\begin{array}{r}2.34 \\
\pm \quad 0.23\end{array}$ & $\begin{array}{r}2.41 \\
\pm 0.25\end{array}$ & $\begin{array}{r}2.16 \\
\pm 0.27\end{array}$ & $\begin{array}{r}2.14 \\
\pm 0.07\end{array}$ \\
\hline $\begin{array}{l}\text { Triceps Skinfold } \\
(\mathrm{mm})\end{array}$ & $\begin{array}{r}12.2 \\
\pm \quad 6.6\end{array}$ & $\begin{array}{r}14.6 \\
\pm \quad 2.9\end{array}$ & $\begin{array}{r}15.7 \\
\pm \quad 7.1\end{array}$ & $\begin{array}{l}- \\
-\end{array}$ \\
\hline $\begin{array}{l}\text { Upper Arm } \\
\text { Circumference }(\mathrm{cm})\end{array}$ & $\begin{array}{r}29.5 \\
\pm 2.8\end{array}$ & $\begin{array}{r}29.3 \\
\pm \quad 2.3\end{array}$ & $\begin{array}{r}25.9 \\
\pm \quad 3.2\end{array}$ & - \\
\hline
\end{tabular}


It can be noted that Olympic participants, both men and women, were found to be taller than their club counterparts. The body mass index of males was greater than that of females, but male values were low by comparison with non-athletes (Goldbourt and Medalie 1974).

Values for skinfold thickness showed no abnormality (Wilmore and Behnke 1969, 1970), values for men being lower than for women as expected. In addition, international class men had lower values than club men involved in similar activity categories.

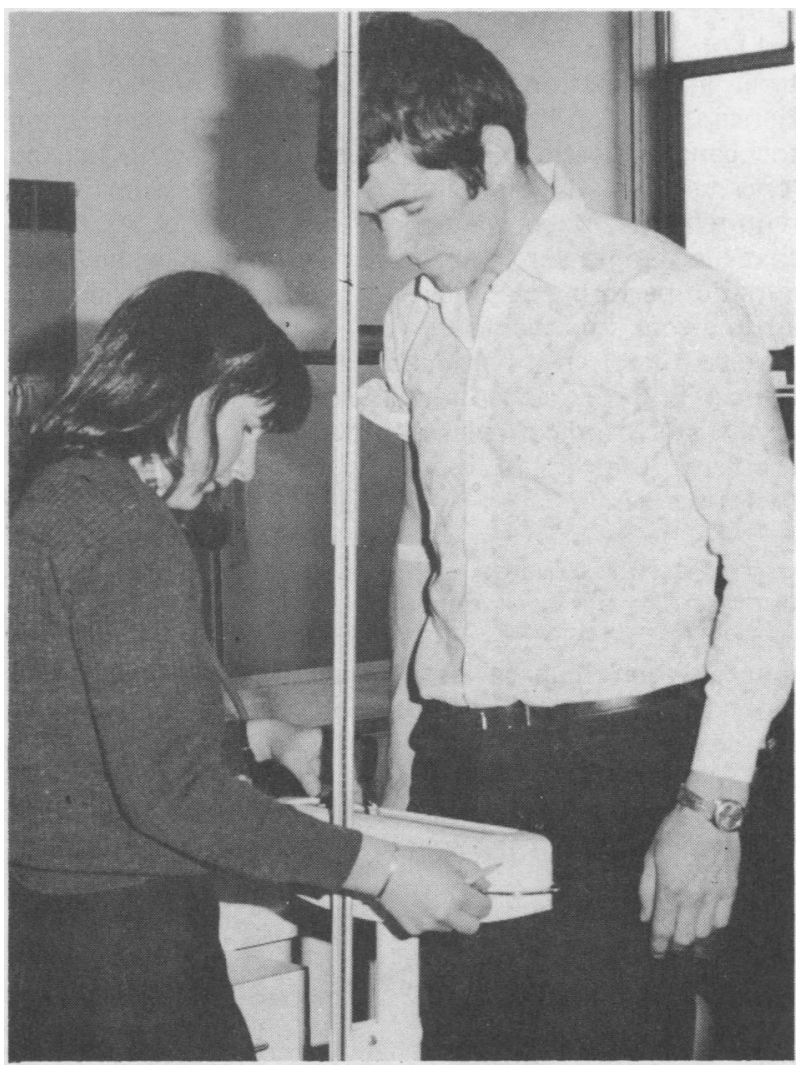

Fig. 5 Anthropometry with international assman

\section{HAEMATOLOGY RESULTS}

Of the routine haematological assessments carried out, the most significant finding was in relation to the red cell counts. The mean values for both international and club class male participants $\left(4.2\right.$ and $4.7 \times 10^{12} / 1$ respectively) was observed to be at the lower end of the reference range $\left(5.5 \pm 1.0 \times 10^{12} / 1\right)$.

Similarly low results can be noted for the international class female participants with a value of $3.8 \times 10^{12} / 1$ compared with the reference range of $4.8 \pm 1.0 \times 10^{12} / 1$.

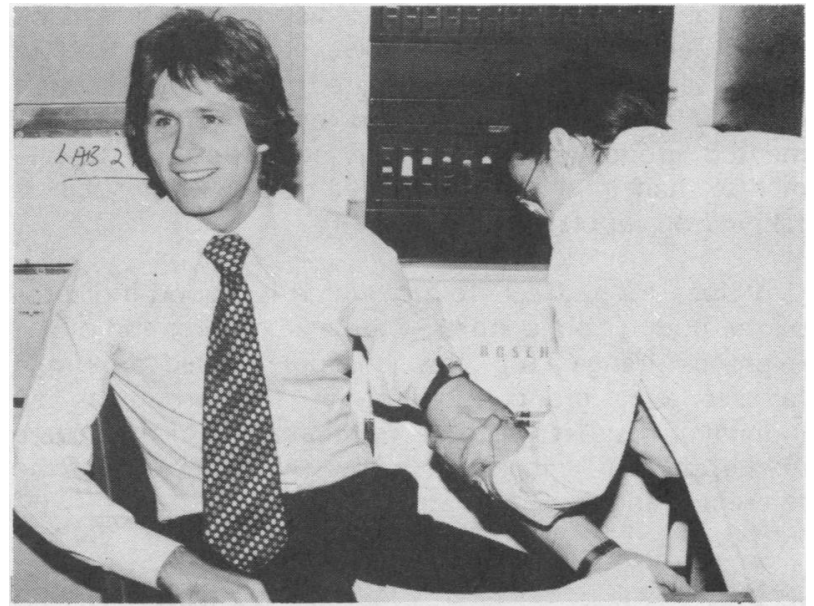

Fig. 6 Eamonn Coghlan

\section{BIOCHEMISTRY RESULTS}

The results indicated desirably elevated levels of high density lipoprotein cholesterol in both international subjects (men $2.1 \mathrm{mmol} / \mathrm{l}$; women $2.5 \mathrm{mmol} / \mathrm{l}$ ) and club competitors (men $2.5 \mathrm{mmol} / \mathrm{l}$; women $3.2 \mathrm{mmol} / \mathrm{l}$ ) when compared with the reference standard of 1.0-2.1 $\mathrm{mmol} / \mathrm{l}$.

Similarly, average values for triglycerides were observed to be at the lower end of the reference range (0.7-2.3 $\mathrm{mmol} / \mathrm{l})$, for both international subjects (men $1.2 \mathrm{mmol} / \mathrm{l}$; women $0.9 \mathrm{mmol} / \mathrm{l})$, and club participants (men and women $1.1 \mathrm{mmol} / \mathrm{l}$ ).

The results of some biochemical tests for nutrient stores of iron, folate and B12 are shown in Table IV. These were carried out on a small group $(n=13)$ near the end of the study period when the facilities to carry out such assessments were made available to the Centre.

TABLE VI

Additional biochemistry results

\begin{tabular}{|c|c|c|c|c|c|}
\hline & \multirow{3}{*}{$\begin{array}{l}\text { Reference } \\
\text { Standard }\end{array}$} & \multicolumn{4}{|c|}{ I-Class } \\
\hline & & \multicolumn{2}{|l|}{ MEN } & \multicolumn{2}{|c|}{ WOMEN } \\
\hline & & n & $x$ & $n$ & $x$ \\
\hline $\begin{array}{l}\text { Serum Ferritin } \\
(\mu \mathrm{g} / 1)\end{array}$ & $10-300$ & $\begin{array}{l}* \text { U } 8 \\
* \text { * S } 5\end{array}$ & $\begin{array}{l}52 \\
85\end{array}$ & $\begin{array}{l}\text { U } 2 \\
\text { S } 2\end{array}$ & $\begin{array}{l}22 \\
40\end{array}$ \\
\hline $\begin{array}{l}\text { Serum B12 } \\
\text { (ng/1) }\end{array}$ & $150-1000$ & $\begin{array}{l}\text { U } 12 \\
S 1\end{array}$ & $\begin{array}{l}531 \\
395\end{array}$ & $\begin{array}{l}\text { U } 4 \\
\text { S } 0\end{array}$ & $\begin{array}{c}401 \\
-\end{array}$ \\
\hline $\begin{array}{l}\text { Serum Folate } \\
(\mu g / 1)\end{array}$ & $2.5-20$ & $\begin{array}{l}\text { U } 13 \\
\text { S } 0\end{array}$ & $\begin{array}{l}8.9 \\
-\end{array}$ & $\begin{array}{l}\text { U } 4 \\
\text { S } 0\end{array}$ & $\begin{array}{r}4.7 \\
-\end{array}$ \\
\hline $\begin{array}{l}\text { Red Cell Folate } \\
(\mu \mathrm{g} / 1)\end{array}$ & $150-640$ & $\begin{array}{l}\text { U } 13 \\
\text { S } 0\end{array}$ & $\begin{array}{c}381 \\
-\end{array}$ & $\begin{array}{l}\text { U } 4 \\
\text { S } 0\end{array}$ & $\begin{array}{c}179 \\
-\end{array}$ \\
\hline
\end{tabular}


It can be seen that iron reserves as represented by serum ferritin values were lower in females than in males; serum ferritin is considered a reliable indication of body stores. They were also lower in the unsupplemented group (those who did not take iron supplements) than in the supplemented group (those subjects taking iron supplementation).

Values for red cell folate, which is a good indicator of the body's folate stores, were at the lower end of the reference range for the unsupplemented Olympic females as a group. Looking at this group on an individual basis, it was observed that some of them were in the deficient range (i.e. below the lower end of the reference range).

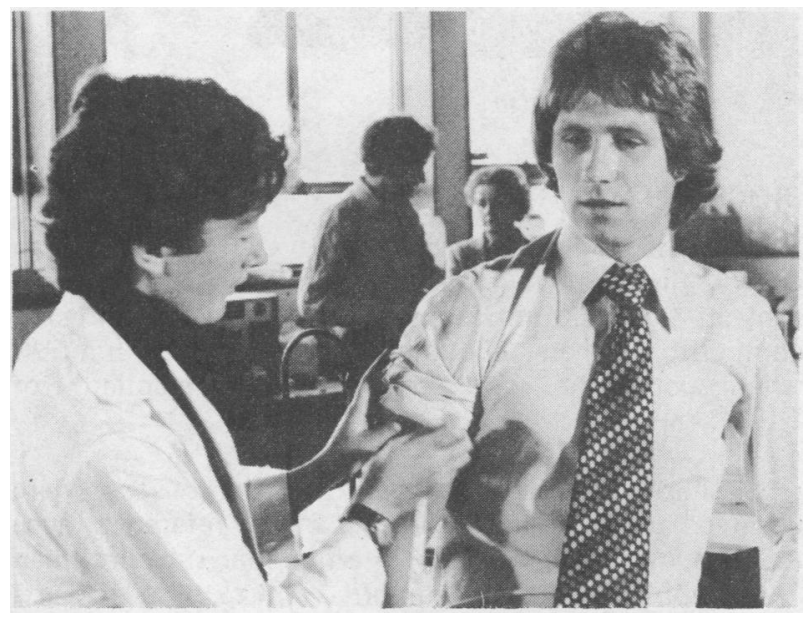

Fig. 7 Eamonn Coghlan

\section{CORRELATION RESULTS}

Specific paired parameters were selected, on the basis of known or expected relationships between nutritional variables, as a basis for correlation analyses. The following were of statistical significance:

(1) The expected relationships between dietary energy and anthropometry were only evident in the sedentary groups of athletes (activity categories 5 and 6).

(2) In the same categories (5 and 6) it was found that fibre intake was correlated negatively with total serum cholesterol levels.

(3) The expected negative correlation between high density lipoprotein cholesterol and body mass index was only found to be significant in the sedentary groups.

These findings suggest the predominant effect of physical activity in determining diet/biolipid/anthropometric relationships. Only where activity levels are relatively low do the expected dietary factors operate as in the general, less active population.

Dietary folic acid was strongly correlated with haemoglobin $(r=0.69 p=0.013)$ in category 3 I-Class female athletes who composed almost $50 \%$ of the female Olympic group. This suggests that dietary folic acid may be a limiting factor in haemoglobin formation in this group.

\section{DISCUSSION}

Athletic and sports performance demands optimal structural and functional conditions of the human body. Hence, nutrition holds an important role in maintaining the general health of the athlete, in providing for the long term needs of training and for the short term requirements of competition. It is not to be expected that diet alone will achieve dramatic effects in terms of athletic performance, nevertheless, it is justifiable to assume that improvement in diet eliminates a potentially adverse factor in athletic training and as such may be critical in producing optimal performance. The results of this study indicate several actual and potential dietary problems that could represent limitations in athletic performance.

The trend towards a higher fat and lower carbohydrate diet has been encountered in other such studies as Stordy in 1980 . It could be accounted for by the fact that at such high levels of energy intake there is a tendency towards choosing a more concentrated energy source.

The tendency towards high protein intakes is a common finding in those studies relating to the nutrient

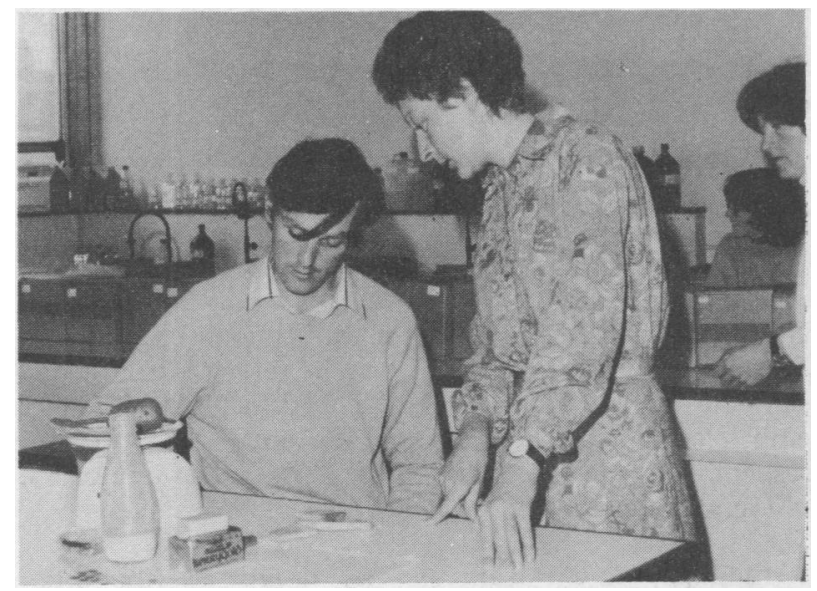

Fig. 8

Ms. M. G. T. Ingoldsby instructing international oarsman in weighed food method 
intake of athletes such as Ferro-Luzzi, Topi et al (1975); Steele (1970) and Stordy (1980). The protein requirements of athletes is still a controversial subject described by Consolazio et al (1975), Durnin (1975) and Eller and Viru (1975), some arguing that high protein intakes confer no additional benefit in physical activity. Other investigators conclude that the need for protein varies with the intensity of training (Laritcheva, Yalovaya et al, 1978). i.e. intensive training periods, prior to or in preparation for events when muscle building is involved, required a higher protein intake; in the region of $2.2 \cdot 2.6 \mathrm{~g} / \mathrm{kg}$ body $\mathrm{wt} /$ day is considered desirable.

Athletes must be made aware of the uselessness of high protein intakes in isolation. It must be emphasised that unless energy requirements are met, high protein intakes are not beneficial and may even reduce performance capacity by increasing renal work load.

The possible adverse effect of high protein intakes on calcium retention merits attention, according to Linkswiler (1976). Most of the studies on calcium requirements have been carried out without reference to the level of protein intake of the participants and results obtained are contradictory. Studies carried out in the U.S. between 1970 and 1975 (Linkswiler 1976), showed that calcium metabolism is profoundly affected by the level of dietary protein. They also indicate that at protein intakes of $142 \mathrm{~g} /$ day, calcium balance was not maintained when the diet contained $1400 \mathrm{mg}$ calcium. Even more important was the fact that the subjects failed to adapt to this situation even though they had been accustomed to high protein diets in the past. Schwartz, et al (1973) found that adolescent males in a stage of rapid growth retained calcium at protein intakes of $93 \mathrm{~g}$ and calcium intakes of $1800 \mathrm{mg}$. These findings suggesting adverse effects of a low calcium - high protein diet are of direct relevance to the results of this study; they question the validity of applying a reference standard of $800 \mathrm{mg}$ calcium/day for all or even the majority of participants, when total protein intakes in male participants were so high $(152 \mathrm{~g} / \mathrm{day}$ (I) and $136 \mathrm{~g} /$ day (C)); they also imply that advice to participants with calcium intakes greater than $1600 \mathrm{mg} /$ day on reducing their calcium intakes may not be appropriate over the long-term.

Figures for thiamin intakes of 1-Class participants are lower than those of their club class counterparts, particularly in the case of men with values of $0.59 \mathrm{mg} / 1000$ kcals compared with $0.63 \mathrm{mg} / 1000 \mathrm{kcals}$. This could be explained by the higher total energy intakes in the I.Class men and so. a possible tendency towards eating more concentrated energy sources such as refined carbohydrates (sugar, white flour and its products) and fat (butter or margarine, fried foods, confectionery) both of which are practically devoid of thiamin. This observation emphasises the need for athletes with very high energy intakes to be aware of the fact that a major dependence on the concentrated energy sources mentioned may not satisfy their requirement for vitamins such as thiamin.

Values for nicotinic acid, although high, are noticeably lower in the 1.Class subjects than in the C-Class. Again, this could be attributed to the higher total energy intake and the dependence on more concentrated sources of energy, as mentioned in relation to thiamin. Vitamin B6 is a co-factor in the conversion of tryptophan to nicotinic acid. It could be argued that there may be some justification for reducing the calculated amount of nicotinic acid derived from tryptophan in assessing the diets of those groups whose B6 intakes fell below the reference standard.

The question of tryptophan metabolism may be important in women whose B6 intakes fell well below the reference standard of $2.0 \mathrm{mg} /$ day. The most obvious dietary cause was the lower quantity of animal protein consumed, especially concentrated B6 sources like liver and kidney. However, although the women consumed nearly as much protein as their male counterparts on a body weight basis, their total protein intakes were much lower, which may imply a reduced requirement for pyridoxine. A question arises as to whether the value of $2.0 \mathrm{mg} / \mathrm{day}$ was too high considering that most individuals would have difficulty in attaining such intakes.

Nevertheless, if athletes do have an increased need for protein during intense training, this does imply an increased B6 requirement to allow for the anabolic and catabolic processes of amino acids. Although data on the frequency of female participants taking oral contraceptives were not recorded, it is likely that lout of a group of 28 women of childbearing age) some of the group would fall into this category. Since recent work by Luhby et al (1971) has suggested that supplementation of the order of $30 \mathrm{mg}$ pyridoxine/day is effective in correcting the negative effects of oestrogens on tryptophan metabolism, this would imply that the reference standard of $2 \mathrm{mg} /$ day is far from sufficient for this group.

Sub-optimal iron intake was another feature of the female diet in contrast to that of the males. This is not surprising since the reference standard for women was almost double that for men and, furthermore, women consumed on average less haem iron from sources such as meat, especially liver and kidney.

This indicates the need for appropriate dietary advice to encourage the increased consumption of good iron sources. It is recognised that women have higher requirements than men because of menstrual loss; however, the question arises as to whether increased physical activity raises the requirement even further and if so, by how much? Since information on this subject is limited, it seems wise that nutritional studies should, where 
possible, be accompanied by biochemical indicators of iron store depletion and iron deficiency such as serum ferritin, or red cell protoporphyrin. Without these, the assessment of iron status based solely on iron intake is insufficient.

Additional biochemical determinations carried out on a small sample of subjects during the follow-up study showed that serum ferritins were lower in women than in men and lower in the unsupplemented than in the supplemented athletes. It is possibly not valid to make conclusions on the results of such small numbers of subjects but the results do suggest the possibility that many more Irish female athletes may be in Stage 1 of iron deficiency anaemia or even in further advanced stages leading to overt anaemias with reduced capacity to transport oxygen, according to Cook and Finch in 1979. This is one group where in addition to an increased intake of dietary iron, iron supplements may also be useful.

Perhaps one of the most important findings of the study was the low folate intakes. This was also one of the principal findings of a recent study on the dietary intakes of U.K. Olympic athletes by Stordy in 1980. The dietary cause can be directly attributed to a lack of both good animal and vegetable sources of folate in the diet, i.e. liver and kidney, and fresh green leafy vegetables such as broccoli, brussels sprouts and spinach. Serum folate levels fall below normal 3-6 weeks after a folate deficient diet as described by Krumdieck in 1976, and it was observed that the mean serum folate values for female participants in the study were at the lower end of the reference range. Red cell folate falls more slowly after a folate deficient diet and is a better indicator of tissue stores; again, the female Olympic competitors showed low red cell folate levels, some of which were in the deficient range.

These preliminary results show the need for further investigation, correlating dietary folate intakes with body folate stores, and using a control group of sedentary individuals. This may provide some answers as to whether female athletes are more at risk of developing folate deficiency because of their lower dietary intakes and whether intensity and duration of training increase folate requirements.

In conclusion, it may be stated that this study demonstrates the existence of dietary problems in a group of elite athletes that potentially may limit performance. The results emphasise the need for increased nutrition education and dietary monitoring as part of the overall training programme where optimal performance is sought.

\section{ACKNOWLEDGEMENTS}

The authors wish to thank Patricia Brennan, Brid Keenan and Ailish Kennedy who carried out the analyses of blood samples and also the third year dietetic students, for their help in demonstrating the recording techniques of the weighed food intake to the participants.

Thanks are also due to Martin Dunne for his help with the computer analysis of the data and to the phlebotomist, Carmel Johnston, who took the blood samples.

Finally, thanks are due to Jean Cantwell for the typing and presentation of the various drafts.

\section{REFERENCES}

Consolazio, C. F., Johnson, H. L., Nelson, R. A., Dramise, J. G. and Skala, J. H., 1975 "Protein metabolism during intensive physical training in the young adult". Am.J.Clin.Nutr. 28: 29-35.

Cook, J. D. and Finch, C. A., 1979 "Assessing iron status of a population". Am.J.Clin.Nutr. 32: 2115.

Dal Monte, A., 1969 "A proposal for the biomechanical classification of sports". Med Sport 22: 12.

Durnin, V. G. A., 1975 "Protein requirements and physical activity". International symposium on sportsmen's nutrition. Abstracts. Warszava. 118.

Durnin, V. G. A., (Ed. J. Parizkova and V. A. Rogozkhin), 1978 "Protein requirements and physical activity". (International Series on Sports Sciences, Vol. 7.) Nutrition, Physical Fitness and Health. First Edition. Published by University Park Press, Baltimore.

Eller, A. K. and Viru, A. A., 1975 "Protein metabolism during prolonged exercise". Questions of athletes nutrition. Abstracts of the report of the International Symposium, Leningrad. 45-46.

Ferro-Luzzi, A., Topi, G. C. and Caldarone, G., 1975 "Habitual dietary intakes of Italian athletes applying for the Olympic Games, 1972". Med.Sport 28: 109-125. 
Goldbourt, U. and Medalie, J. H., 1974 “Weight-height indices". Brit.J.Prev.Soc.Med. 28: 116-126.

Krumdieck, C. L., 1976 Folic Acid. Nutrition Reviews Present Knowledge in Nutrition. Fourth Edition. Published by the Nutrition Foundation Inc., Washington D.C.

Laritcheva, K. A., Yalovaya, N. I., Shubin, V. I., Smirnov, P. V., (Ed. J. Parizkova and V. A. Rogozkin), 1978 "Study of energy expenditure and protein needs of top weight lifters". International Series on Sports Sciences, Volume 7. Nutrition, Physical Fitness and Health. First Edition. Published by University Park Press, Baltimore.

Linkswiler, H. M., 1976. Calcium Nutrition Reviews - Present Knowledge in Nutrition. Fourth Edition. Published by The Nutrition Foundation Inc., Washington D.C.

Luhby, A. L., Brin, M., Gordon, M., Murphy, M. and Spiegel, H., 1971 "Vitamin B6 metabolism in users of oral contraceptive agents. Abnormal urinary xanthurenic acid excretion and its correction of pyridoxine". Am.J.Clin.Nutr. 24: 684-693.

Marr, J. W., 1971 "Individual dietary surveys: Purposes and methods". World Review of Nutrition and Dietetics 13: 105-164.

Paul, A. A. and Southgate, D. A. T., 1978. McCance and Widdowson's The Composition of Foods. Fourth Edition. HMSO, London.

Schwartz, R., Woodcock, N. A., Blakely, J. D. and Mackellar, I., 1973 "Metabolic responses of adolescent boys to two levels of dietary magnesium and protein. 11. Effect of magnesium and protein level on calcium balance. Am.J.Clin.Nutr. 26: $519-523$

Steele, J. E., 1970 "A nutritional study of Australian Olympic athletes". Med.J.Austr. 2: 119-123.

Wilmore, J. H. and Behnke, A. R., 1970 "An anthropometric estimation of body density and lean body weight in young women" Am.J.Clin.Nutr. 23 (3): 267-274.

Wilmore, J. H. and Behnke, A. R., 1969 "An anthropometric estimation of body density and lean body weight in young men". J.Appl.Physiol. 27 (1): 25-31.

Recommended intakes of nutrients in the United Kingdom, 1969. Reports on Public Health and Medical Subjects No. 120, HMSO, London.

Recommended Dietary Allowances, 1974. Eighth Edition. National Academy of Sciences, Washington D.C.

Handbook of Human Nutritional Requirements, 1974. Monograph Series No. 61, World Health Organisation, Geneva.

Senate Select Committee on Nutrition and Human Needs, May 1977 "Dietary goals for the United States". Nutrition Reviews 35 (5): 122-124.

O'Shea, B. Personal Communication, 1979, Dept. of Mathematics, Dublin Institute of Technology, College of Technology, Kevin Street, Dublin 8.

Stordy, B. J. Personal Communication, 1980, Division of Nutrition and Food Science, Department of Biochemistry, University of Surrey "Nutrient intakes of U.K. athletes during training". 